\title{
Örümcek Isırığı İle Gelişen Şiddetli Sistemik Toksisite ve Dermonekroz
}

\author{
Severe Systemic Toxicity and Dermonecrosis Caused By a Spider \\ Bite \\ Can CELILOĞLU, Orkun TOLUNAY, Ulaş ÖZDEMIR, Asena SUCU, Ümit ÇELIKK
}

Adana Şehir Eğitim ve Araștırma Hastanesi, Çocuk Sağlı̆̆ı ve Hastalıkları Kliniği Yüreğir/ADANA

\begin{abstract}
ÖZ
Loxosceles cinsi örümcekler, insanoğlunun yerleșim yerlerinde yaşayabilen, insanoğluna zarar verebilme potansiyeline sahip bir türdür. Literatürde örümcek ısırıklarına dair yapılan yayınlarda sistemik belirti ve bulgular nadiren bildirilmiștir. Sunacağımız olgu daha öncesinde sağ|ıkı olan dört aylık kız çocuğu olup huzursuzluk, boyunda şişlik, böcek ısırması şüphesi nedenleri ile başvurdu. Boyunda ve skalpte ödemi belirginleşen, solunum sıkıntısı olan ve şuuru bozulan olgu çocuk yoğun bakıma yatıııldı. Entübe edilen olguda koagülopati, dolaşım bozukluğu, CRP yüksekliği nedenleri amprik antibiyoterapi başlandı. Çadırda yaşadığı bildirilen olguya amprik olarak akrep serumu ve takibinde yllan serumu verildi. Olgunun ailesi yașadıkları çadırda sonraki günlerde buldukları örümceği yoğun bakım ekibimize bildirdi ve ısırık bölgesine uyan bölgede dermonekroz gelișmiș olan olgunun tanısı aydınlatıldı. Dermonekroz debride edildi ve takibe alındı. Olgu bir ayllk yatışı sonrasında dermonekroz haricinde belirgin sekel oluşmaksızın taburcu edildi. Literatürde nadiren bildirilmiş olan örümcek sokmasına bağlı şiddetli sistemik bulgular ve dermonekroz varlı̆ı nedenleri le vakamızı sunulmaya değer bulduk.
\end{abstract}

Anahtar Sözcükler: Çocuk, Dermonekroz, Damar içi pıntılaşma, Örümcek ısırı̆̆ı

\begin{abstract}
Loxosceles spiders can live in the household and have the potential to cause harm to human beings. Systemic signs and symptoms have rarely been reported on spider bites in the literature. We present a formerly healthy four-monthold girl applied to the hospital with complaints of irritability, swelling of the neck and suspected insect bite. The patient was admitted to the pediatric intensive care unit because of edema in the neck and scalp, with respiratory distress and impaired consciousness. Case was intubated, and emprical antibiotherapy started due to the coagulopathy, circulatory failure, CRP positivity. Empirical scorpion serum and snake serum was applied to the patient living in rural areas. Several days after the admittance, the family reported that they found a spider in the tent so the diagnosis of the case which developed a dermonecrosis around the bite zone was clarified. Dermonecrosis was debrided and followed-up. The patient was discharged without any apparent sequelae except for dermonecrosis after one month of hospitalization. We found it worthwhile to submit our case due to severe systemic findings and dermonecrosis due to spider stings which are rarely reported in the literature.
\end{abstract}

Key Words: Child, Dermonecrosis, Disseminated Intravascular Coagulation, Spider bite

\section{GiRiş}

Örümceklerin günümüzde 50.000'den fazla türü olduğu bilinmektedir (1). Yaşamalanlarımızdabulunabilen örümceklerin çoğu insanlar için zehirli değildir (2,3). Yaklaşık 200 örümcek türünün insanoğluna zararlı olduğu düşünülmektedir (4). Kahverengi örümcek olarak da bilinen Loxosceles cinsi (genus), insanoğlunun yerleșim yerlerinde yaşayabilen, ısırığıyla insanoğluna zarar verebilme potansiyeline sahip bir türdür (5).
Ülkemizde, yaşam alanında örümcek olduğu bilinen bir vakada göz etrafında gelişmiş olan akut dermonekroz vakasında ELISA yöntemi ile Loxosceles zehri saptandığı bildirilmiştir (6). Ülkemizde örümcek ısırıklarına dair 82 vakalık bir seri bildirilmiştir (1). Bu bildirimde dokuz vakada hipertansiyon, hipotansiyon, hipertermi, somnolans gibi sistemik belirti ve bulgular bildirilmiştir ancak vakamız gibi solunum sıkıntısı yaratan şiddetli ödem, koagülopati, lökopeni bildirilmemiştir. Ülkemizdeki Loxosceles cinsi örümcek ısırıklarına bağlı olarak literatüre geçmiş vaka 
sunumlarında; lokal doku şişliği, dermonekroz, yüzeysel cilt nekrozu, göz etrafında hiperpigmentasyon ve skarlașma bildirilmiștir (5-12).

Vakamızı; solunum sıkıntısı, lökopeni ve koagülopati ile komplike bir tablonun gelişmesi, tabloyu aydınlatacak örümceğin çadırda bulunup fotoğraflanması, gelişmiş olan dermonekrozun görsellerinin çarpıcı olması, cilt lezyonları hariç nörolojik vb. sekel olmaksızın iyileşmesi nedenleri ile sunulmaya değer bulduk.

\section{OLGU SUNUMU}

Miadında normal yolla 3000 gram doğmuş olan öncesinde tamamen sağlıklı dört aylık kız bebek başvurusundan üç gün önce ateşlenmiş. Vaka Adana'nın Sarıçam ilçesinden başvurmaktaydı. Başvurulan hekimin verdiği antipiretik ilaç tedavisi ile ateşi geçmiş. İki gün sonrasında boyun şişliği fark edilen ve ateşi tekrarlayan vakaya başvurdukları hekim böcek ısırığı olabileceğini ifade edip ayaktan izlem önermiş. Aynı gün içerisinde bebeğin göz etrafında ve yüzünde şişliğin belirginleşmesi sonrası hasta tarafımıza yönlendirilmiş. Başvurusu anında vücut ısısı doğal sınırlarda, oda havası solurken cilt oksijen saturasyonu \% 85-88, nabzl: 148/dk, solunum sayısı: 52/dk, arteryel kan basıncı:70/45 mmHg'di. Boyunda ve kafa derisinin tümünde solunum yollarını tehdit edebilecek belirgin ödem ve ensede bir adet bir cm çapında, çeperi kabuklu, merkezi ekimotik olan, etraf dokularda ödem, endürasyon ve dalgalı ekimoz/dolaşım bozukluğu alanları mevcut olan șüpheli ısırık izi kaydedildi (Resim 1).

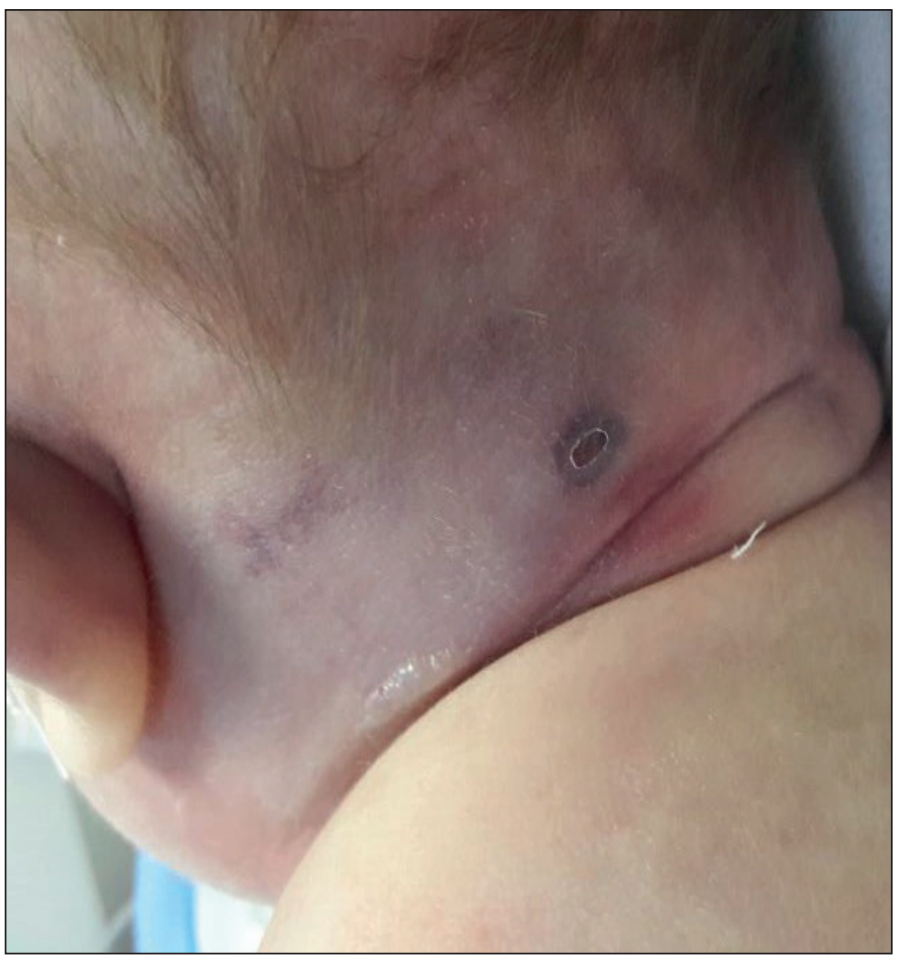

Resim 1: Saçlı deride belirgin ödem.
Vakaya maske oksijen desteği ve IV (intravenöz ) hidrasyon uygulandı, tansiyon değerleri düşük seyreden ve takipnesi devam eden, şuuru letarjik olan, Glasgow koma skoru 9 kaydedilen, vaka çocuk yoğun bakım ünitesine yatııldı. Tetkiklerinde tam kan sayımında beyaz küre değeri: $1.65 \times 10^{3} / \mu \mathrm{l}, \mathrm{Hb}: 10 \mathrm{gr} / \mathrm{dl}$, Trombosit: $475 \times 10^{3} / \mu$, Protrombin zamanı: 31 saniye (INR: 3), parsiyel tromboplastin zamanı: 45.9 saniyeydi. CRP: $14.3 \mathrm{mg} /$ dl $(0-0.5 \mathrm{mg} / \mathrm{dl})$ saptanan vakada serum biyokimyasında Alb: $2.6 \mathrm{gr} / \mathrm{dl}$ (3.8-5.4 gr/dl), Na: $128 \mathrm{mmol} / \mathrm{L}$ (135-145 mmol/L) mevcuttu. Kabulünde transaminaz değerleri doğal sınılarda olan vakanın 24 saat sonra alınan serum kreatin kinaz: 3014 U/L (0-170 U/L) olarak saptand.

Yatışının yaklaşık sekizinci saatinde kafa derisindeki ve boyundaki ödemi artan, solunumu zorlaşan ve şuuru uykuya meyilli hale gelen hasta entübe edilerek mekanik ventilatöre bağlandı (Resim 2). Ateş, beyaz küre düşüklüğü, takipne ve CRP pozitifliği mevcut olan ve sepsis ekarte edilemeyen vakaya kan ve idrar kültürleri alınarak ampirik IV vankomisin (40 mg/kg/gün) ve meropenem (60 mg/kg/gün) başlandı. Yatışın üçüncü günü

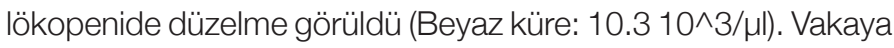
koagülopati mevcudiyeti nedeni ile 2 mg IV K vitamini ve 2×15 cc/kg/doz IV taze donmuş plazma desteği başlandı. Yaşa göre arteriyel tansiyon değerleri alt sınırda olan (arteryel tansiyon 70/40 $\mathrm{mmHg}$ ) septik tablosu olan vakaya takibinin sekizinci saatinde dolaşımı desteklemek maksadıyla dopamin (10 mcg/kg/dk) ve dobutamin $(10 \mathrm{mcg} / \mathrm{kg} / \mathrm{dk}$ ) IV infüzyonları başlandı. Yatışın ikinci günü hipotansiyon sebat edince (arteryel tansiyon 65/35 $\mathrm{mmHg}$ ) IV $0.1 \mathrm{mcg} / \mathrm{kg} /$ dakika dozunda adrenalin ve $0.1 \mathrm{mcg} /$ $\mathrm{kg} /$ dakika dozunda noradrenalin infüzyonları tedaviye eklendi.

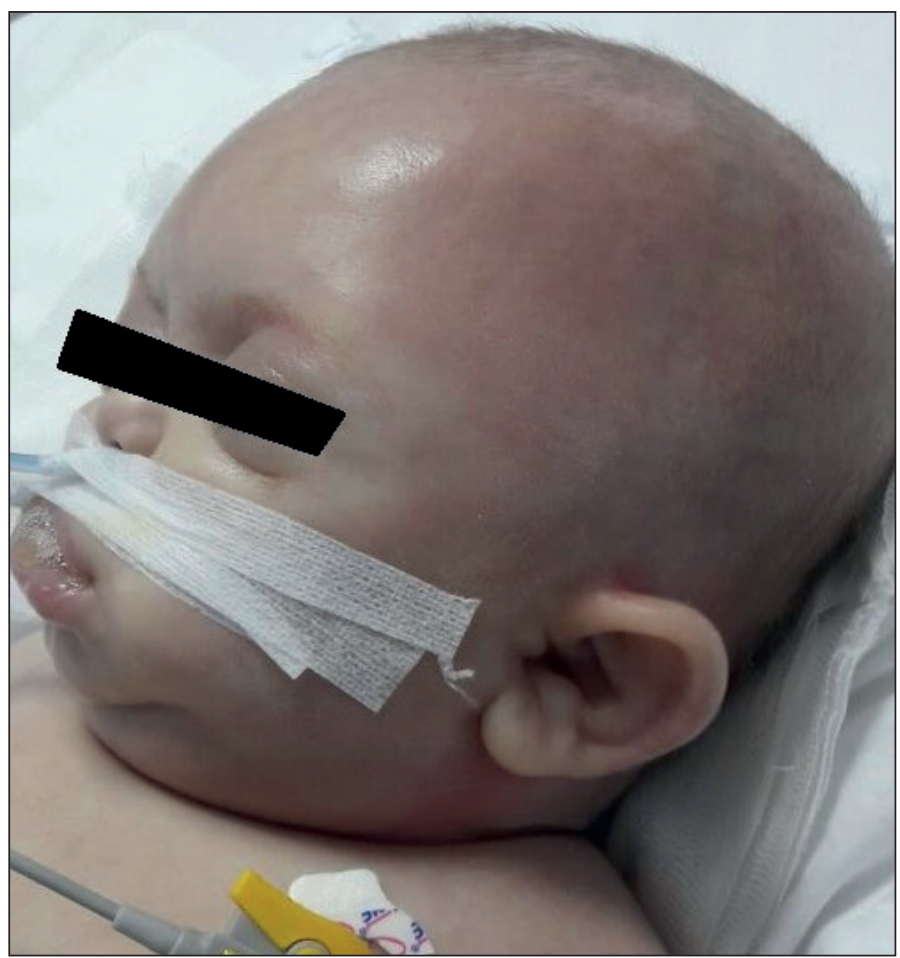

Resim 2: Kafa derisi ve boyundaki ödemi artan, solunumu zorlaşan vakanın görünümü. 
Hiponatremi ve hipoalbuminemiye yönelik IV sodyum klorür ve iv albumin replasmanı başlandı. Ani kötüleşme, koagülopati mevcudiyeti ile olası intrakranial kanama vb. açılarından çekilen beyin tomografisinde; beyin parankiminde kanama veya ek patolojiye rastlanmadı, solda temporoparietooksipital, sağda temporoparietal bölgede galeal ödem/hemoraji? izlendiği rapor edildi. Kafa ve boyun yüzeyel ultrasonografide; boyun cilt altında diffüz ödem izlendiği, bilateral karotid arterlerde akımların doğal olduğu bildirildi. Takibinde genel durum bozukluğu ve skalp ödemi sebat eden ve etiyolojisi aydınlatılamayan vakanın Suriye'den gelen göçmenlerin barındııılığı çadıllardan birinde yaşaması ve başvurdukları yaz döneminde Adana kırsalında akrep ve yılan sokması sık görülebilmesi dolayısı ile, akrep serumu ve takiben yllan serumu ampirik olarak verildi. Ödemleri mevcut vakaya $4 \times 1 \mathrm{mg} / \mathrm{kg} / \mathrm{doz}$ IV feniramin ve $4 \times 0.2 \mathrm{mg} / \mathrm{kg} /$ doz deksametazon iv tedavi başlanıldı.

Skalptekive boyun bölgesindeki geniş çaplı ödem ve endürasyon yatışın üçüncü günü sebat eden vakaya aralıklı IV furosemid verildi ancak takibinde bu tedaviden fayda görmemesi üzerine tedavi kesildi. Hastanın koagülasyon parametreleri takip edildi ve kademeli olarak taze donmuş plazma infüzyonları azaltılarak kesildi. Takibinin dördüncü günü olguya nazogastrik yoldan yaşa uygun formula mama ile beslenme başlandı ve kademeli olarak arttırıldı. Takibinde tansiyon ölçümleri normal seyreden vakanın vazoaktif ilaç infüzyon tedavileri kademeli olarak kesildi. Vaka, yatışının yedinci günü spontan solunumunun yeterli olması üzerine ekstübe edildi.

Bebeğin boyun cildinin posterior kesimindeki yarası etrafında doku kaybı/dermonekroz ile iyileşme görüldü (Resim 3).

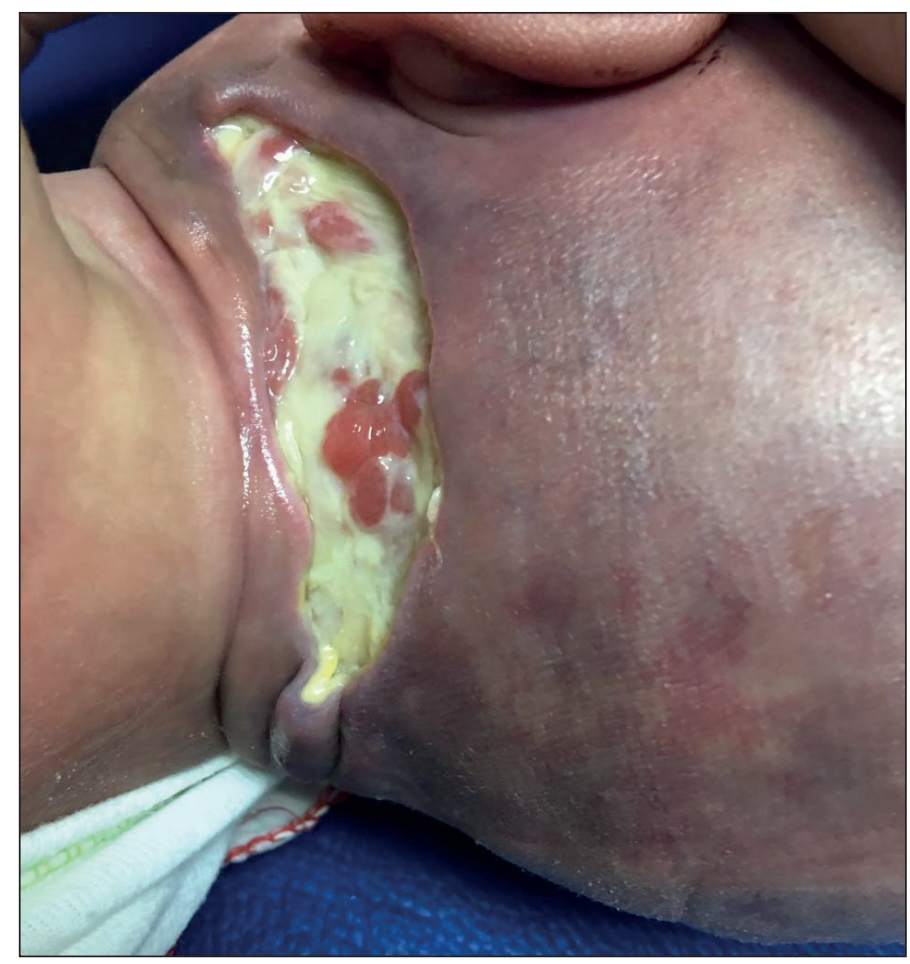

Resim 3: Örümcek ısırığı etrafında doku kaybı/dermonekroz
Plastik ve rekonstrüktif cerrahi ekibi ile konsülte edilen vakaya rifampisin, bacitracin ve neomisin sülfat içeren lokal antisepsi/ pansuman başlanıldı, takibinde debride edildi. Aile, yatışın ilk haftası içerisinde çadırlarında buldukları Loxosceles cinsi örümceği kliniğimize getirdi ve klinik tablonun bu örümcek ısırığına bağlı gelişen Loxoscelism tablosu ile uyumlu olduğu görüldü. Takibinde antibiyoterapisi kesilen ve ağızdan yaşına uygun diyetle beslenen vaka dermonekroz açısından plastik ve rekonstrüktif cerrahi kliniği takibine alınarak önerilerle taburcu edildi.

\section{TARTIŞMA}

Örümcek, ısırdığı esnada görülemezse veya yaşam alanında ısırıktan sorumlu tutulan örümcek tecrübeli biyolog/araknolog tarafından tanımlanamazsa, bir lezyonun örümcek ısırı̆̆ına bağlı geliştiğini teşhis etmek zor olacaktır (13). Olgumuzda çadırda bulunan örümceğin ve lezyonun görselleri, örümcekler ve ısırıkları hususunda tecrübeli bir bilim insanının görüşlerine sunulmuştur, tipik bir Loxosceles örümceğine benzediği tarafımıza iletilmiştir.

Loxosceles cinsi örümcek sokması ile oluşan klinik tablo literatürde "loxoscelism" olarak adlandırımaktadır. Ülkemiz coğrafyasında loxoscelism'e neden olan tek türün "Akdeniz kahverengi örümceği" olarak da ifade edilen Loxosceles rufescens olduğu kabul görmektedir (5). Bu türün İstanbul, Mardin, Kahramanmaraş, Hatay, Antalya, Muğla, Aydın illerinde saptandığı bildirilmiştir (7).

Çocuklarda loxoscelism'e bağlı morbidite hakkında yeterli bilgi literatürde henüz mevcut değildir. Erişkinleri de içine alan, Amerika Birleşik Devletleri menşeili 10 ylllık bir retrospektif çalışmada ısırıkların tümünün evde olduğu ve çoğunlukla kırsal kesimde gerçekleştiği bildirilmiştir (14). Vakamı da benzer şekilde kırsalda ev olarak kullandıkları çadırda ısırı̆̆a maruz kalmıştı.

"Loxoscelism" kliniğinde; artralji, soğuk terleme, ateş, lökositoz, döküntü, hemolitik anemi, yaygın damar içi pıhtılaşma, hemoglobinuri, miyoglobinuri, akut böbrek yetmezliği hatta ölüm bildirilmiştir $(14,15)$. Loxosceles türü örümcek ısırığı sonrası çocuklarda \%1.1 oranında yoğun bakım intiyacı geliş̦iği bildirilmiştir (16). Hastamızın ilk yatış döneminde belirgin lökopeni mevcudiyeti literatür bilgilerinden farkllık arz etmektedir (14). Hastanın alınan kan kültüründe üreme saptanmaması, lökopeniye sebep olabilecek ısırığa bağlı gelişen bakteriyel invazyon olasılı̆ıını dışlar niteliktedir.

Loxoscelism tedavisinde temel basamak elevasyon, etkilenen uzvun immobilizasyonu, buz uygulanması, yara bakımı ve tetanoz profilaksisidir (17). Hiperbarik oksijen tedavisi, dapson, antihistaminikler (ör. siproheptadin), antibiyotikler, dekstran, steroidler, vazodilatörler, heparin, nitrogliserin, elektrik şoku, cerrahi eksizyon ve anti-venom gibi tedavilerin uygulandığı literatürde mevcuttu ancak etkin bir tedavi seçeneği üzerinde bir görüş birliği yoktur (17). 
Sunduğumuz vaka daha öncesinde sağlıklı olan dört aylık kız çocuğu olup böcek ısırması, akrep sokması, yılan sokması, ısırığa bağı septik şok ön tanıları ile takip edilmekte iken, vakanın ailesi yaşadıkları çadırda sonraki günlerde buldukları örümceği yoğun bakım ekibimize göstermiş ve tanı aydınlatılabilmişti. Ülkemizde dermonekroz ile seyreden vakalarda örümcek sokması intimalinin akılda tutulmasında fayda görmekteyiz. Örümcek sokması düşünülen olguların bir kısmında bir-iki haftalık süre içerisinde dermonekroz gelişebileceğinden klinik takiplerin bu intimali kapsayacak şekilde planlanmasının önem arz edeceğini düşünüyoruz.

\section{Teşekkür}

Lezyonun ve ailenin getirdiği örümceğin fotoğraflarını danıştığımız Prof. Dr. Abdullah BAYRAM'a değerli katkıları dolayısıyla teşekkür ederiz.

Çelişkili Çıkarların Beyanı: Yazar, bu makalenin araştıııması, yazarlığı ve yayına ilişkin herhangi bir çıkar çatışması olmadığını beyan etmiştir.

Finansman: Yazarlar bu makalenin araștırıması, yazarlığı veya yayımı için mali destek almadı.

\section{KAYNAKLAR}

1. Cesaretli Y, Özkan O. A clinical and epidemiological study on spider bites in Turkey. Asian Pac J Trop Med 2011;4:159-62.

2. Dyachenko P, Ziv M, Rozenman D. Epidemiological and clinical manifestations of patients hospitalized with brown recluse spider bite. J Eur Acad Dermatol Venereol 2006;20:1121-5.

3. Isbister GK, Gray MR. A prospective study of 750 definite spider bites, with expert spider identification. Q J Med 2002;95:723-31.

4. Diaz HJ. The global epidemiology, syndromic classification, management, and prevention of spider bites. Am J Trop Med Hyg 2004;71:239-50.
5. Gülalp B, Kayıpmaz AE, Altınörs MN, Sancak Z, Yiğit N. Loxosceles: A Case Healed Completely Without Any Necrotic Tissue by Emergency Department and Review of the Literature. JAEM 2013;12:101-4.

6. Akdeniz S, Green JA, Stoecker WV, Gomez HF, Keklikçi SU. Diagnosis of loxoscelism in two Turkish patients confirmed with an enzyme-linked immunosorbent assay (ELISA) and non-invasive tissue sampling. Dermatol Online J 2007;13:11.

7. Yiğit N, Bayram A, Ulaşoğlu D, Danışman T, Ocal IC, Sancak Z. Loxosceles Spider Bite in Turkey (Loxosceles rufescens, SICARIIDAE, ARANEAE). J Venom Anim Toxins incl Trop Dis 2008;14:178-87.

8. Dişel NR, Şahan Ö, Açıkalın A. Necrotizing arachnidism: Diagnosing with inspection in insect bites. Gaziantep Med J 2014;20:338-41.

9. Ergin Ş, Aktan Ş, Erdoğan BŞ, Kara IG, Evliyaoğlu D. Bir Nekrozitan Araknidizm Olgusu. Turkderm 2006;40:17-9.

10. Köse A, Çete Y, Eken C, Köse B. Loxosceles Isırığına Bağlı Gelişen Nekrotizan Araknidizm: Olgu Sunumu ve Literatürün Gözden Geçirilmesi. Türkiye Acil Tıp Dergisi 2006;6:181-5.

11. Taşkesen M, Akdeniz S, Taş T, Keklikçi U, Taş MA. A rare cause of severe periorbital edema and dermonecrotic ulcer of the eyelid in a child: brown recluse spider bite. Turk J Pediatr 2011;53:87-90.

12. Keklikçi U, Akdeniz S, Sakalar YB, Çakmak SS, Ünlü K. Loxosceles reclusa bite to the eyelid. Eur J Ophthalmol 2008;18:633-5.

13. Vetter RS, Bush SP. Additional considerations in presumptive brown recluse spider bites and dapsone therapy. Am J Emerg Med 2004;22:494-5.

14. Hubbard JJ, James LP. Complications and outcomes of brown recluse spider bites in children. Clin Pediatr (Phila) 2011;50:252-8.

15. Vorse H, Seccareccio P, Woodruff K, Humphrey GB. Disseminated intravascular coagulopathy following fatal brown spider bite (necrotic arachnidism). J Pediatr 1972;80:1035-7.

16. Elbahlawan LM, Stidham GL, Bugnitz MC, Storgion SA, Quasney MW. Severe systemic reaction to Loxosceles reclusa spider bites in a pediatric population. Pediatr Emerg Care 2005;21:177-80.

17. Swanson DL, Vetter RS. Bites of Brown Recluse Spiders and Suspected Necrotic Arachnidism. N Engl J Med 2005;352:700-7. 